\title{
気体透過膜の性能評価法
}

\author{
仲川勤 \\ 明治大学工学部 干214 川崎市多摩区生田 5158
}

\section{Evaluation of Gas Permeable Polymer Membranes}

\section{Tsutomu Nakagawa}

School of Engineering, Meiji University, 5158 Ikuta, Tama-ku, Kawasaki, Kanagawa 214

Various methods of test for gas transmission rate of polymer membranes were summerized, which cover the determination of the steady state rate of transmission of a gas through polymers in the form of film, sheeting, laminates and polymer coated papers. They provide for the determination of (a) gas transmission rate (GTR), and (b) permeability coefficient in the case of homogeneous materials, and (c) diffusion coefficient.

Methods are divided into two main groups; A) non-equable pressure method and B) equable pressure method. In the non-equable pressure method, the pressure difference exists across the sample and the permeated gas through the sample is measured by a monometric method or volumetric method. In the manometric method, when the lower pressure side of the sample is initially evacuated at $10^{-5} \sim 10^{-6} \mathrm{mmHg}$, the transmission of the gas through the test specimen is indicated by a change in pressure which is measured by Mc Leod gauge or an MKS Baratron pressure transducer. This method is called "high-vacuum technique". When the lower pressure side of the sample is initially evacuated at $10^{-1} \sim 10^{-2} \mathrm{mmHg}$, the transmission of the gas is measured by a cell manometer, namely a closed end U-tube manometer. This method is called "low-vacuum technique". In the volumetric method, the low pressure side of the sample is maintained near atmospheric pressure and the transmission of the gas is indicated by a change in volume. In the equable pressure method, the total pressures of the both sides of the sample are equal. The permeated gas is measured by a detector system, for example, cas chromatography, thermal conductivity. When oxygen is a test gas, the oxygen electrode is available.

In both methods (A) and (B), the principles, apparatus and calculations were described here in detail.

\section{1. 緒言}

合成高分子膜であれ，液膜であれ，膜が境界となって 二つの空間を仕切り,この空間に気体の分圧差が存在す るとき，気体は必ず高圧側（高濃度側）から低圧側（低 濃度側）に膜を通過して移動する。この現象を気体の “transport”あるいは “permeation”之呼ぶ. “permeation”は “gel permeation chromatograph”の用い方か ら“浸透”と訳されることもあるが，膜を通しての気体 の移動の場合には “透過”と訳す方が良からう。気体透
過膜の性能評価法はここでは高分子膜を気体が透過する 量を測定する方法に限定して述べる.

高分子膜を気体が透過する速度は膜を構成している高 分子の物理的 (結晶性など), 化学的 (極性基の種類, 分布の仕方など）な性質に依存することはいうまでもな いが，気体透過性を評価する場合ｉ）膜の透過面積， ii ) 膜の厚さ, iii）膜の温度, iv) 膜の両側の気体圧力 にも依存する. この他, 気体以外の水蒸気, 水, 有機蒸 気等が共存する場合にも，高分子膜によっては大きな影 響をうける場合がある。気体透過膜の性能評価にはこれ 
Table 1 気体透過膜の測定原理の分類と特長

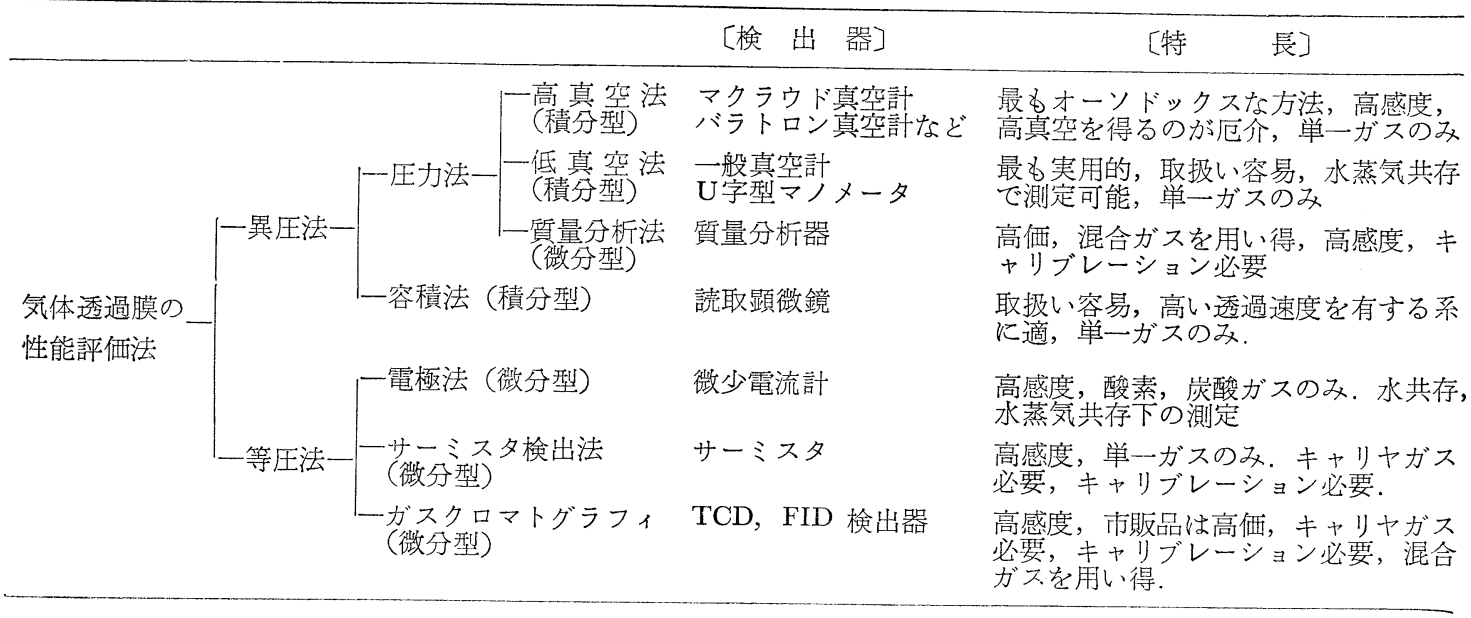

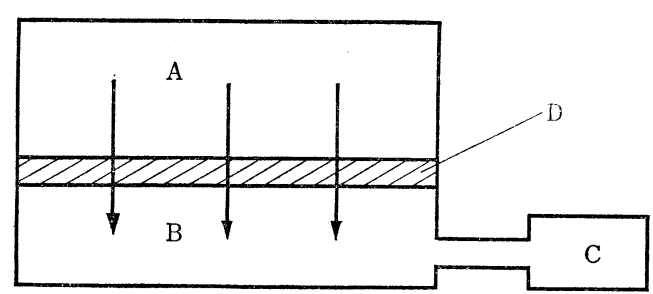

Fig. 1 気体透過度測定の原理
$\mathrm{A}:$ 高い分圧 (高圧側)
$\mathrm{B} ：$ 低い分圧末たは真空（低圧側）
$\mathrm{C}:$ 検出器

らの因子が含まれていなければならない。

\section{2. 測定方法の原理の分類および特長}

測定法の原理は測定試料である朕を境界膜として, 二 つの空間を仕切り, 異圧法, 等圧法でも膜の両側の気体 の分圧をか光, 高、分圧の側から低い分圧の側に透過し た気体の量を検出器で測定し, 単位時間あたりで表わす (Fg. 1). 測定法を Table 1 亿分類し, 検出器, 特長を 記した。

異圧法は測定試料の膜の両側の空間のそれぞれの全圧 が異なる場合である，通常は低圧側を真空に保つが，容 積法では後述するょうに低圧側は大気圧である. 圧力法 の名称は低濃度側を真空とし, 透過した気体に上る低圧 側の圧力增加を測定することからこの名称がある。

等圧法は測定試料の両側の全圧は等しいが測定する気 体の分圧が異なる場合で，気体は分圧の高い側(高圧側) から低い側（低圧側）に透過する，透過側は常に混合が
スを形成しているから，測定しょうとする気体だけが検 出できる検出器が必要である。

積分型とは透過した気体が積算されて行く型であり， 微分型とは透過した気体を常に除去して測定する型で時 間対透過した気体の量の関係を示す透過曲線はそれぞれ

Fig. 2 に示す形となる.

\section{3. 気体透過度（気体透過速度, 気体透過率), 気体透過係数}

気体透過の実験曲線である透過曲線の勾配と, 後述す る測定装置の諸次元から気体の透過量 $q$ が得られる. $q$ と気体透過度 $R$ の関係怯次式で示される.

$$
\begin{aligned}
& q=R\left(P_{1}-P_{2}\right) A t \\
& R=q /\left(P_{1}-P_{2}\right) A t \\
& R: \mathrm{cm}^{3}(\mathrm{STP}) / \mathrm{m}^{2} \cdot 24 \mathrm{hr} \cdot \mathrm{atm}
\end{aligned}
$$

ここで, $P_{1}, P_{2}$ はそれぞれ高圧側, 低圧側の分圧, $A$ は透過面積, $t$ は時間で㐫る。気体透過度 $R$ は膜厚が 不明でめっても求められ, 測定温度での膜の実用的な值 である. 非多孔質膜では $q$ は膜厚に逆比例するから $q$ は,

$$
\begin{aligned}
& q= \frac{P}{l}\left(P_{1}-P_{2}\right) A t \\
& P=q \cdot l /\left(P_{1}-P_{2}\right) A t \\
& \quad P: \mathrm{cm}^{3}(\mathrm{STP}) \cdot \mathrm{cm} / \mathrm{cm}^{2} \cdot \mathrm{sec} \cdot \mathrm{cmHg}
\end{aligned}
$$

(3) 式で定義される $P$ は気体透過係数と呼ばれる. $P$ と $R$ の関係は (3) (4) 式の比較からわかるように

$$
R=\frac{P}{l} \text { または } P=R \cdot l
$$




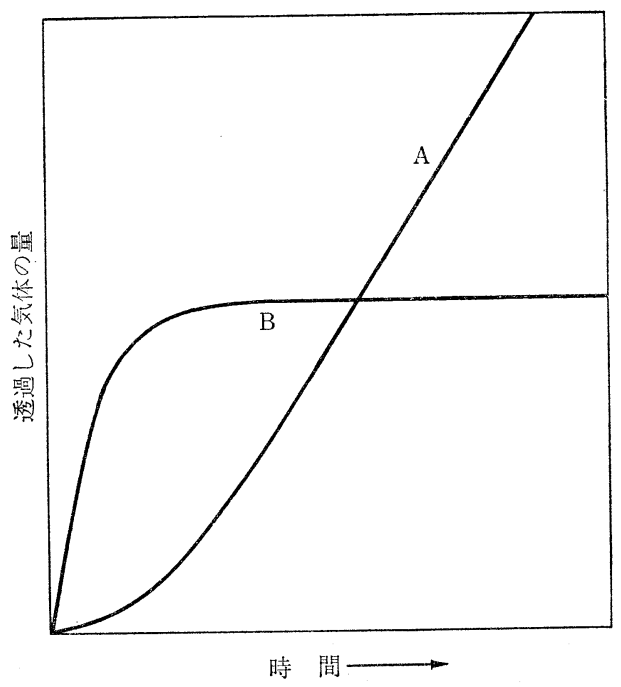

Fig. 2 透過曲線 $\mathrm{A}:$ 積分型 $\mathrm{B}:$ 微分型

$P$ は気体透過膜の材料の物性值であり, 通常, 膜厚 1 $\mathrm{cm}$, 膜面積 $1 \mathrm{~cm}^{2}$, 時間 1 秒, 圧力差 $1 \mathrm{cmHg}$ あたりの 気体の透過量 $\mathrm{cm}^{3}$ を $0^{\circ} \mathrm{C}, 1$ 気圧 (Standard Temperature and Pressure, STP) に換算した值である.膜の材 料, 気体の種類, 温度によって異なるが,一般的に $10^{-14} \sim 10^{-8}$ オーダにある. 気体透過膜の性能評価とい うのは,この $R$ および $P$ を求めることである.

\section{4. 異圧法による測定}

\section{1 圧力法}

高圧側から低圧側に透過して来た気体の量を低圧側の 圧力増加として測定し, 透過曲線を描き, 直線部分（定 常状態）の勾配から透過度を，この直線部分の延長と時 間軸との交点 (Fig. 3 参照), 与なわち遅れ時間 (time $\log$ ) から抎散係数を計算する. American Society for Testing Materials (ASTM) や日本工業規格 (JIS) にも 採用されて拈り，広く用いられている方法である．圧力 法の5ち質量分析法以外《低圧側に真空計を検出器とし て設置している．測定開始時の低圧側の真空度として $10^{-5} \sim 10^{-6} \mathrm{mmHg}$ (torr) を用いる場合を高真空法（質 量分析法は高真空法の一種）と呼んでいる. これに対し $10^{-1} \sim 10^{-2} \mathrm{mmHg}$ の真空度を用いる方法が低真空法で める。高真空法と低真空法とは装置の複雑さ, 操作の簡 便性に扣いて相当の開きがある。一般に真空ラインに括 いて, $10^{-5} \sim 10^{-6} \mathrm{mmHg}$ の高真空を得るのはそれ程困

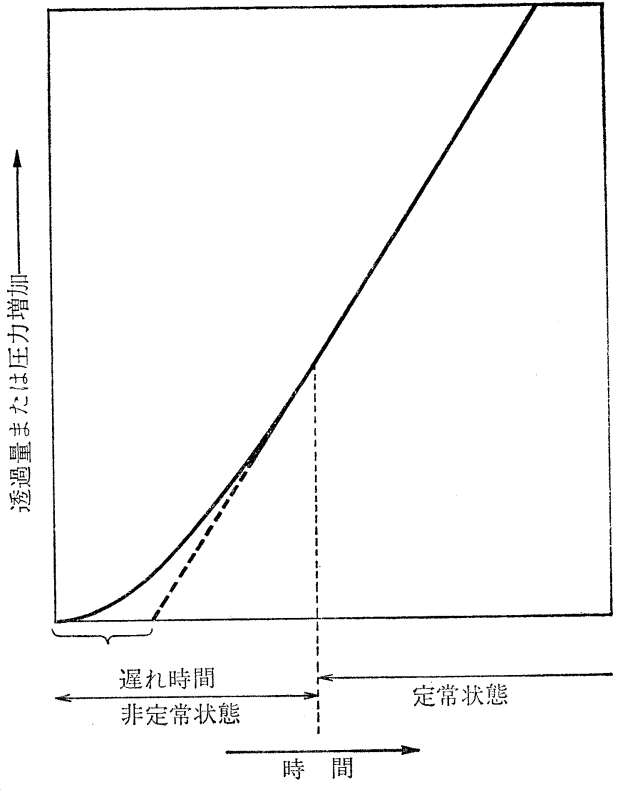

Fig. 3 圧力法に打ける透過曲線

難ではないが，測定試料を装填した状態でこの真空度を 保持するには細かい技術を必要とする，両方法の比較を Table 2 にまとめた。

\subsection{1 高真空法による測定法}

代表的な例としてマクラウド真空計を用いた測定方法 について詳述する. 装置の系統図を Fig. 4 に示す.こ の装置の製作にあたっては充分な強度を有する鋼鉄製の 架台を固定し, パイレックスガラスで組立て, 真空コッ クは特に高級なものを選ぶ. ガス溜めは $3 \sim 5 l$ の容量 のフラスコが適し，数個を組み込んで括くと，気体の種 類を変えて透過実験が連続して容易に行える．油拡散ポ ンプか水銀拡散ポンプかの選択は，いずれを用いても到 達真空度には大きな差はないが，有機溶媒を用いて製膜 した測定試料からの有機溶媒の脱着や真空コックのグリ 一スの洗浄に用いた有機溶媒が油拡散ポンプに入って, 真空の引きが覀くなる括とれがあり，この場合油の交探 が厄介であること（液体窒素のトラップが效いている間 はこの持それはない）から筆者は水銀拡散ポンプを用い ている、マクラウド真空計は回転式マクラウド真空計を 用いても良いが，測定の回数の多さを考慮すれば，水銀 を多く必要とするが，水銀が押し上げられる型の方が好 ましい。この場合上昇させた水銀を下降させる真空ポン プが更に独立に必要となる。 
Table 2 高真空法と低真空法の比較

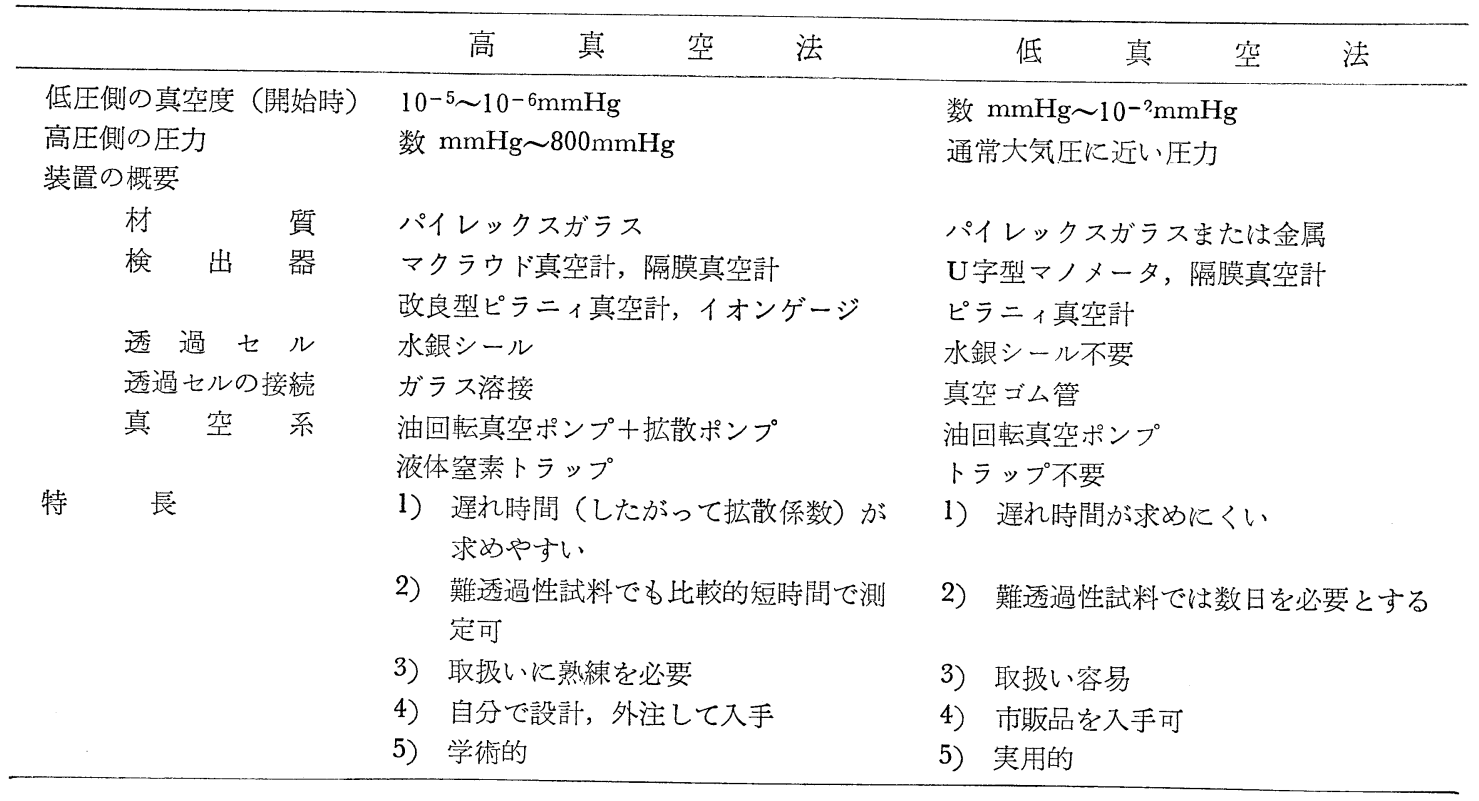

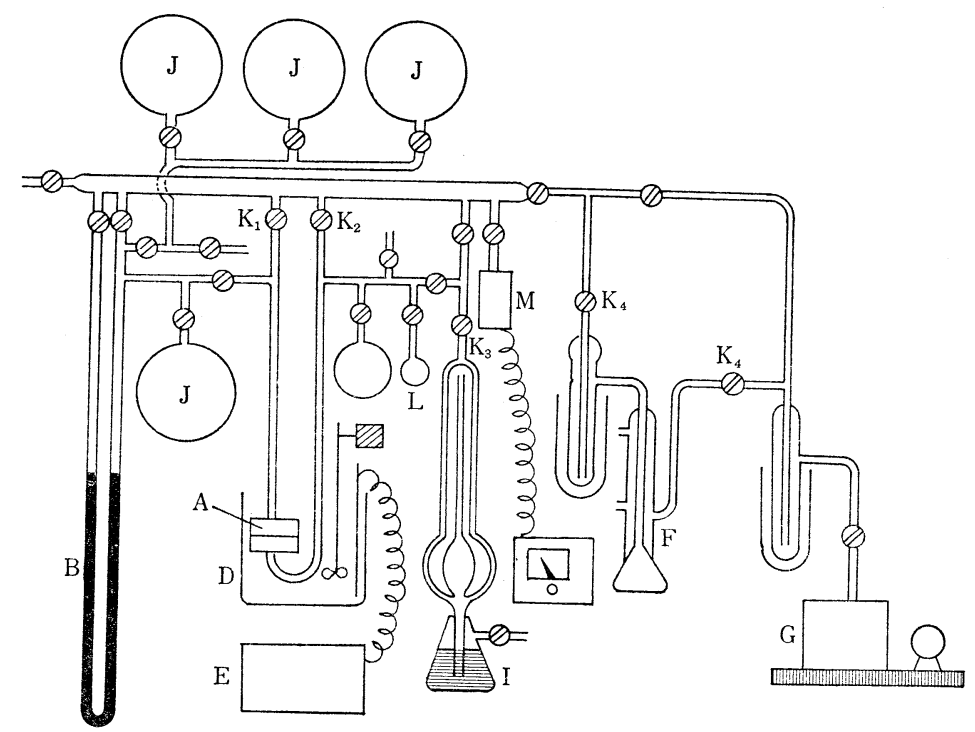

Fig. 4 高真空法気体透過率測定装置
A：透過セル
B：圧力計
$\mathrm{C}:$ 記録計
$\mathrm{D}:$ 恒温槽
$\mathrm{E}:$ 恒温装置
$\mathrm{F}:$ 拡散ポンプ
$\mathrm{G}:$ 油回転真空ポンプ
$\mathrm{H}:$ 液体窒素冷却トラップ
I : マクラウド真空計 $\mathrm{J}$ ：ガスだめ
$\mathrm{K}:$ 真空コック
$\mathrm{L}$ : 標準容積 $\mathrm{M}$ ：ピラニィ真空計

透過セルの構造を Fig. 5 と示す. 透過セルの高圧側, 低圧側のステンレススチール製パイプはコバールシール を経てパイレックスガラスの真空ラインに溶接される.
透過セルは測定試料の装填部分と大気の間を水銀で埋め るいわゆる水銀シールを施してあるので, このまま恒温 水槽中に浸漬することができる，恒温水槽の温度精度を 


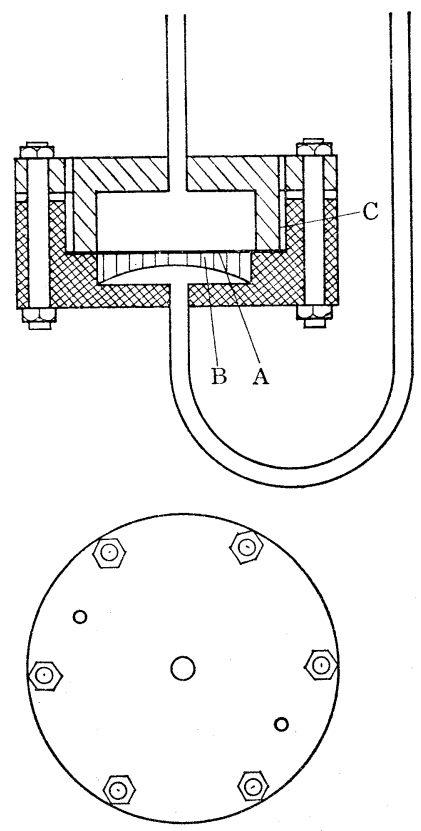

Fig. 5 高真空法に用いる気体透過セル
$\mathrm{A}:$ 測定試料
$\mathrm{B}:$ 金属多孔板
$\mathrm{C}:$ 水銀シール簓所

少なくとも設定温度の $\pm 0.5^{\circ} \mathrm{C}$ 以下に保つことが好ま しい.

\section{[高真空型気体透過率測定装置の操作手順]}

操作の手順は以下に記すが，試料を透過セルに装填し， 真空ラインに接続した後の手順の要点は，i）低圧側を 真空にする，ii）高圧側を真空にする（この手順を逆に すると圧力が逆転し測定試料が破損する), iii）測定試 料の両側を真空にする，iv）低圧側の真空もれ，透過セ ル・測定試料からの脱着ガスの試験（ブランクテスト） をする，V）測定ガスを高圧側に導入して測定を開始す る.

1）測定試料の装填. 透過セルの多孔板の上に，これ と同じ大きさの沪紙あるいは多孔質テフロン膜を置く。 測定試料と透過セルが接触するプレートに薄くシリコン グリースを塗布し密着を完全にする．厚さ $0.5 \mathrm{~mm}$ 以 下のガスケット (パッキング) として無充填のシリコン ゴムめるいはブチルゴムをのせ，透過セルの上部を静か にかぶせて，ボルトで透過セルの下部と結合させる。

2）透過セルをガラス溶接で真空ラインに接続する. 溶接の作業を容易にするために真空ラインの透過セルを 溶接する近くに真空ベローズを挿入する工夫がなされる
場合もある.

3) マクラウド真空計の上のコック $\left(\mathrm{K}_{3}\right)$ (Fig. 4 参 照) を閉じて真空ラインから弧立させて置き，高圧計の コック $\left(\mathrm{K}_{1}\right)$ を閉じ，ピラニィ真空計の針の動きを見る. もし測定試料にピンホールがあるか, 測定試料の装填が 不完全であれば，高圧側にある大気圧の空気の流入のた め, ピラニィゲージの針のふれが極めて大さい，この場 合は透過セルを真空ラインからガラスを切断して, 取り はずし，試料を交換することになる，マクラウド真空計 のコック $\left(\mathrm{K}_{3}\right)$ 学閉じて沶くのは高い圧力の気体の流入 による破損を防ぐためである.

4) 低圧側のコック $\left(\mathrm{K}_{2}\right)$ を閉じ，高圧側のコック $\left(\mathrm{K}_{1}\right)$ を開き，10-1 $\mathrm{mmHg}$ オーダの真空度に達したら 低圧側コック $\left(\mathrm{K}_{2}\right)$ を開き装置の全系を真空に引く。こ こで透過セルに水銀シールを施す.

これまでは油回転真空ポンプのみで真空にする，これ をあら引きと呼んでいる。

5）油回転ポンプによるあら引きで，水銀拡散ポンプ の場合, 作動する背圧である 10-1 $\mathrm{mmHg}$ オーダにふた たび達したら水銀拡散ポンプのコック $\left(\mathrm{K}_{4}\right)$ を開き，系 全体を $10^{-5}$ ～10-6 $\mathrm{mmHg}$ となるまで充分に真空に引 $<$.

6)（ブランクテスト） 低圧側のコック $\left(\mathrm{K}_{2}\right)$ だけを 閉じて真空系から弧立させ, 高圧側は高真空に保持した まま，低圧側の真空度の低下をチェックする，許容され るブランクテストの真空度の低下の大きさは測定試料の 気体透過度により異なる. 真空度低下の原因はａ）透過 セルの真空もれ， b ）低圧側にある数個の真空コックか らのもれ，c）測定試料あるいは測定試料の下に敷いて いる汇紙や金属多孔板に含‡れていた吸着物質の脱着に 起因する．しかし長時間真空に引くことで，c）の原因 にもとづく真空度の低下は減少する，透過度が小さい測 定試料の場合には，このブランクテストを小さくするこ とが重要である。

7）らたたび低圧側を高真空とする。ついで，高圧側 $\left(\mathrm{K}_{1}\right)$ ，低圧側のコック $\left(\mathrm{K}_{2}\right)$ を閉じ，ガスだめに充填し てある測定気体を高圧側に導入する。この瞬間が測定時 間0である。

8) 所定時間ごとにマクラウド真空計で圧力を測定し， 透過曲線を描くためのデータを取る。

な怙，マクラウド真空計のかわりにバラトロン圧力計 で自動記録めるいはディジタルで指示される場合も操作 の手順は変らない.

測定が終了したら低圧側をあら引きで真空に引き，つ 
Table 3 測 定 例

\begin{tabular}{|c|c|c|c|c|c|}
\hline \multicolumn{3}{|c|}{ 測 定試 料：改質ポリメチオニン膜 } & 〔測 & \multicolumn{2}{|l|}{ 定] } \\
\hline \multicolumn{2}{|c|}{ 厚: $0.0050 \mathrm{~cm}$} & & 低圧側圧力 & & 低圧側圧力 \\
\hline \multicolumn{2}{|c|}{ 測 定ガス: $\mathrm{CO}_{2}, 62.3 \mathrm{cmHg}$} & 時間（分） & $\times 10^{3} \mathrm{mmHg}$ & 時間（分） & $\times 10^{3} \mathrm{mmHg}$ \\
\hline \multicolumn{2}{|c|}{ 湿 度 : 測定温度 $11^{\circ} \mathrm{C}$, 室温 $27^{\circ} \mathrm{C}$} & 0 & 0.0024 & 16 & 2.34 \\
\hline \multicolumn{2}{|c|}{ 低圧側容積 : $540 \mathrm{~cm}^{3}$} & 1 & 0.0061 & 18 & 31.1 \\
\hline \multicolumn{2}{|c|}{ [ブランクテスト] } & 3 & 0.022 & 20 & 39.2 \\
\hline \multicolumn{2}{|c|}{ 時間（分） 低圧側圧子 } & 5 & 0.351 & 23 & 53.9 \\
\hline 0 & 0.0024 & 7 & 1.65 & 25 & 62.9 \\
\hline 20 & 0.0159 & 9 & 4.30 & 28 & 76.9 \\
\hline 40 & 0.0220 & 11 & 8.21 & 30 & 85.7 \\
\hline \multicolumn{2}{|c|}{ (真空 5 時間) } & 14 & 16.8 & & \\
\hline
\end{tabular}

いで低圧側のコック $\left(\mathrm{K}_{2}\right)$ を閉じ高圧側の測定気体を油 回転ポンプのみの経路で除き, いで低圧側の真空コッ クを開いて全系を真空に引き，ついで水銀拡散ポンプで 真空に引く、特にマクラウド真空計は高真空の状態で保 っためにコック $\left(\mathrm{K}_{3}\right)$ を閉じて扰くことが大切である.

[計算式]

容積が $V \mathrm{~cm}^{3}$ の低圧側に気体が透過したことによっ て $1 \mathrm{mmHg}$ 圧力が増加したとする.この気体の量を標 準状態に換算すれば,

$$
q=\frac{V \cdot 273}{760(273+t)}
$$

高圧側之低圧側の圧力差 $\left(P_{1}-P_{2}\right) \mathrm{cmHg}$, 透過面積 $A$ $\mathrm{cm}^{2}$ で, $d t$ 秒間に $d p \mathrm{mmHg}$ の圧力増加があったとす れば，(2）式より

$$
R=\frac{q}{\left(P_{1}-P_{2}\right) \cdot A} \cdot \frac{d p}{d t}
$$

透過度 $R$ を $\mathrm{cm}^{3}(\mathrm{STP}) / \mathrm{m}^{2} \cdot 24 \mathrm{hr} \cdot \mathrm{atm}$ であらわすとする と, (5)，（6）式打よび単位の換算より，

$$
\begin{aligned}
R= & \frac{d p}{d t} \cdot \frac{V \cdot 273}{760(273+t)} \cdot \frac{10000}{A} . \\
& 24 \times 60 \times 60 \times \frac{76}{P_{1}}
\end{aligned}
$$

透過係数 $P$ を $\mathrm{cm}^{3}(\mathrm{STP}) \cdot \mathrm{cm} / \mathrm{cm}^{2} \cdot \mathrm{sec} \cdot \mathrm{cmHg}$ であらわ すとすると, 測定試料の厚さ $l \mathrm{~cm}$ のとき, $P=R \cdot l$ で あるから表示の単位を考え，

$$
P=\frac{d p}{d t} \cdot \frac{V \cdot 273}{760(273+t)} \cdot \frac{1}{A} \cdot \frac{1}{P_{1}} \cdot l
$$

低圧側の容積は低圧側に接続されている標準容積のフラ スコを用い，低圧側の容積として $\left(V+V_{s}\right)$ および $V$ を用いる透過実験を行って（8）式を用いて計算する. 低生側の容積として $\left(V+V_{s}\right)$, 測定気体の圧力 $P_{1 s}$,
定常状態の勾配 $(d p / d t)_{s}$, 室温 $t_{s}$ とすると, $A, l$ は同 じであるから，

$$
\begin{aligned}
& \left(\frac{d p}{d t}\right)_{s} \cdot \frac{\left(V+V_{s}\right) \cdot 273}{760\left(273+t_{s}\right)} \cdot \frac{1}{P_{1 S}}=\left(\frac{d p}{d t}\right) . \\
& \frac{V \cdot 273}{760(273+t)} \cdot \frac{1}{P_{1}}
\end{aligned}
$$

したがって

$$
V=\left\{\frac{\left(\frac{d p}{d t}\right)_{s}(273+t) \cdot P_{1}}{\left(\frac{d p}{d t}\right)\left(273+t_{s}\right) P_{1 s}}-1\right\} V_{s}
$$

〔測定例】

測定試料としてポリメチオニン膜の酸化物を用いた場 合の実験結果を Table 3 にまとめた。.

測定例の実験条件と結果より $R, P$ は次の様に計算され る.

$$
\begin{aligned}
R=7.79 \times 10^{-5} \times \frac{(540)(273)}{760(273+27)} \times \frac{10000}{15.9} \\
\times \frac{76}{62.3} \times 24 \times 60 \times 60 \\
=3340\left[\mathrm{~cm}^{3}(\mathrm{STP}) / \mathrm{m}^{2} \cdot 24 \mathrm{hr} \cdot \mathrm{atm}\right] \\
P=7.79 \times 10^{-5} \times \frac{(540)(273)}{760(273+27)} \cdot \frac{1}{15.9} \\
\quad \times \frac{1}{62.3} \times 0.0050 \\
=2.54 \times 10^{-10}\left[\mathrm{~cm}^{3}(\mathrm{STP}) \cdot \mathrm{cm} / \mathrm{cm}^{2} \cdot \mathrm{sec} \cdot \mathrm{cmHg}\right]
\end{aligned}
$$

高真空法では遅れ時間が求めやすいので, 次に遅れ時 間から計算される拡散係数について述べる，拡散係数は 次式で求められる.

$$
D=\frac{l^{2}}{6 \theta}
$$

ここで， $\theta$ 日は遅れ時間， $l$ は膜厚である．したがって 


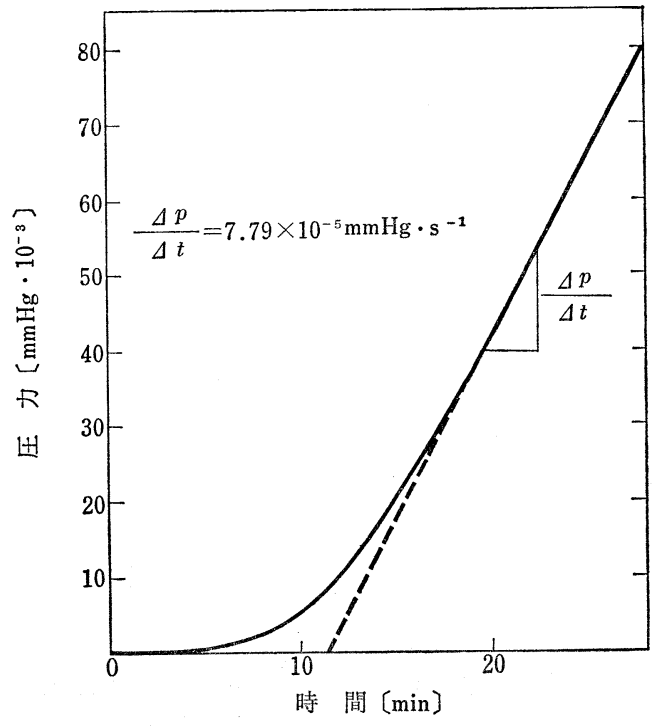

Fig. 6 Table 3 の透過測定データからの透過曲線 $d p / d t$ の決定

測定例では

$$
D=\frac{(0.005)^{2}}{6 \times 96}=4.3 \times 10^{-8}\left(\mathrm{~cm}^{2} / \mathrm{sec}\right)
$$

(11) 式の誘導は Dayness ら1)によって導かれている. すなわち，膜中の気体の濃度の濃度勾配が膜中の位置に よって異なる非定常状態に拈いては，その位置での濃度 の時間変化 $d c / d t$ はこの位置での気体の濃度勾配 $d c / d x$ の場所における変化率に拡散係数を乗じたものに等し w.

$$
\frac{d c}{d t}=D \frac{d}{d x}\left(\frac{d c}{d x}\right)=D \frac{d^{2} c}{d x_{2}}
$$

(12) 式を高真空法に打ける測定条件である次の条件で 解<.

a ) $x=0, t>0$ で $c=c_{1} \quad$ (膜の高圧側の界面の気体 の濃度は測定時間の間 $c_{1}$ である。)

b ) $x=l, t>0$ で $c=0$ （膜の低圧側の界面の濃度は 事実上 0 である。)

c) $t=0$, すべての $x$ で $c=0$ （膜中のどこの位置も 測定開始時は充分に真空に保たれていたので気体 の濃度は0である。)

d) $t=\infty$ で $d c / d t=0 \quad$ （測定時間が充分長い後は時 間あたりの濃度変化はない。)

膜中の $x$ なる位置の, 時間 $t$ での気体の濃度 $C$ は,

$$
C=C_{1}\left(1-\frac{x}{l}\right)-\frac{2 C_{1}}{\pi^{2}} \sum_{n=1}^{\infty} \frac{1}{n} \sin \left(\frac{n \pi x}{l}\right)
$$

$$
\exp \left[-\left(\frac{n \pi}{l}\right)^{2} D t\right]
$$

濃度勾配が一定のとき, 単位面積女たりの透過量 $q$ は

$$
q=-\int_{0}^{t} D\left(\frac{d c}{d x}\right)_{x=l} d t
$$

で求められるから, (13) 式より $d c / d x$ を求め, 時間 $t$ について積分すると， $x=l$ に执いて移動する透過ガス の量 $q$ を示す次式を得る.

$$
\begin{aligned}
q= & D\left[\frac{C_{1} t}{l}-\frac{C_{1} l}{6 D} \sum_{n=1}^{\infty}\left\{1+\frac{12}{\pi^{2}} \frac{(-1)^{n}}{n^{2}}\right.\right. \\
& \left.\left.\exp \left[-\left(\frac{n \pi}{l}\right)^{2} D t\right]\right\}\right]
\end{aligned}
$$

$t=\infty$ で定常状態での透過曲線を表わす次式を得る.

$$
q=\frac{D C_{1}}{l}\left(t-\frac{l^{2}}{6 D}\right)
$$

(16) 式が透過曲線の時間軸 $九$ と交わる点, すなわち遅 れ時間 $\theta$ は，(16) 式より

$$
\theta=\frac{l^{2}}{6 D} \text { または } D=\frac{l^{2}}{6 \theta} \text { （前述） }
$$

\subsection{2 低真空法による測定法}

一般に低圧側の容積が小さく $0.5 \sim 2 \mathrm{~cm}^{3}$ (ASTMD$1434 \mathrm{M}$ 法) $5 \sim 10 \mathrm{~cm}^{3}$ (JIS Z 1707) である. ASTM に 規定されているような小さな容積で，検出方法が水銀柱 の移動による場合, 透過した気体によって水銀柱が押し 下げられることによって生ずる容積変化を補正する必要 がある。つまり低圧側の容積を一定と見なさないことに なる.すでに述べたように真空度は $10^{-2} \mathrm{mmHg}$ 程度 であるので，油回転真空ポンプのみを用いる，また，透 過セルと真空ラインの接続も真空ゴム管で良いので，測 定試料の着脱は高真空法と比較すると簡便である，透過 セルは検出器のマノメータと一体となっており通常セル マノメータと呼ばれる．測定開始に至る操作の手順は高 真空法と本質的に同じであり，拡散ポンプの操作がない だけである。

\subsubsection{1 低王側の容積がー定と見なせる場合}

わが国で広く実用化されている方法である，後述する ASTM D 1434 M 法の改良型と考えて良い。セルマノ メータを Fig. 7 に示す.この図ではU字マノメータの 一方に水銀柱の移動量を検出する光電自記記録ヘッドが 組込なれているが，水銀柱の移動を読取顕微鏡で読み取 り，真空度の低下を正確に知り透過曲線を描くことがで きる．高価であるが高性能の隔膜真空計の一種であるバ ラトロン真空計をU字マノメータのかわりに用い, 直接 自記記録あるいはディジタルに圧力変化を読むことがで 


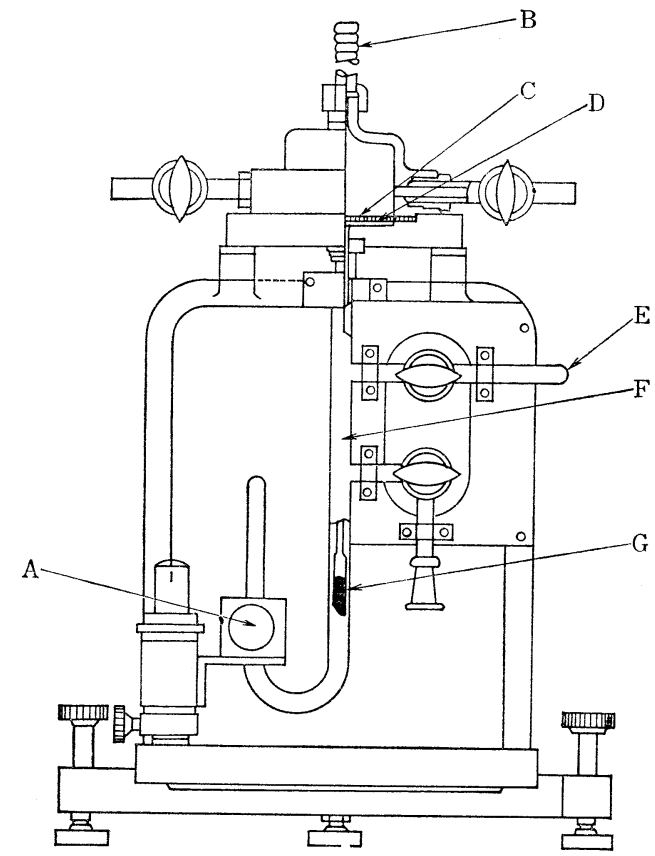

Fig. 7 低真空法に用いる気体透過セルマノメータ （低圧側の容積一定型）
A : 光電式自記記録ヘッド, B : 気体導入口,
$\mathrm{C}$ : 試料, $\mathrm{D}$ : 多孔質ステンレス鋼, $\mathrm{E}$ : 真空ラ
イン接続口, $\mathrm{F}$ ：セルマノメーター, $\mathrm{G}:$ 水銀

きる. バラトロン真空計はレンジの切り替え, あるいは 圧力ヘッドを選択することにより，高真空あるいは低真 空での測定に用い得る。

透過セルの温度設定は透過セルのプレートにサーモエ レメントを直接接触させ，この温度を制御することによ って得られるが，ガスクロマトグラフのカラムのように 透過セルの測定試料の固定部分を恒温槽に保持し所定温 度に保つ装置が好ましい. Fig. 7 に示されたセルは JIS に採用されている透過セルと本質的に同じものである. U字マノメータの内径は $8 \mathrm{~mm}$ 程度であり, 測定は 1 〜 $4 \mathrm{mmHg}$ の圧力变化で測定を終了するために水銀柱の 移動に基づく体積変化は $0.1 \mathrm{~cm}^{3}$ 程度であり，低圧側の 容積が 5〜 10 $\mathrm{cm}^{3}$ であるこの型の透過セルでは高真空 法と同様に低圧側の体積は一定と見なせよう。ささに低 圧側にあるガラスコックに大容量のフラスコを接続する ことによって極めて透過度の大きい測定試料子測定可能 である利点がある. 気体透過度 $R$ や透過係数 $P$ はそ れぞれ（7)，（8）式を用いて計算される.

\subsubsection{2 低圧側の容積が変化する場合}

低圧側の容積が小さい惊ど高感度であるが，U字マノ メータで圧力変化を測定する場合，マノメータのガラス 管に内径が $1.5 \mathrm{~mm}$ 程度の毛細管を用いる。この型の 透過セルの代表的なものが，ASTM D 1434-M 法に規 定されているものであり，透過セルマノメータの概略図 を Fig. 8-a に示す. この型の透過セルマノメータは水 銀の污れによって水銀の移動がスムースでなくなる障害 が生ずるので，毛細管および水銀の清浄なものを用いる 必要がある，透過セルの低圧側を真空に引くとき，水 銀を一時水銀だめに移し, 測定に際しふたたびマノメ一 タに水銀を注ぐ．この操作は透過セルを傾斜させて行 う. 透過セルの測定試料を置くプレートに多孔板のアダ プターを挿入する部分がある。これは低圧側の容積を 8〜10 倍に変えるための工夫である，透過度が大きい測 定試料の場合はアダプターを取りはずせば，容積が大き くなる，自記記録のために毛細管の中には白金抵抗線が 揮入してあり，水銀柱が下降するにつれて抵抗線が露出 し, 抵抗がそれに比例して増大し，これを電気的に増幅 し記録する。

気体透過度 $R$ は次式によって計算される (Fig. 8-b 参照).

$$
R=\frac{4.09 \times 10^{12}}{\left(P_{1}-P_{2}\right) A} \times \frac{d h}{d t}\left[\frac{2 a h-a\left(h_{L}+h_{B}\right)-V_{f}}{R T}\right]
$$

ここで， $a$ は毛細管の断面積 $(\mathrm{mm})^{2}, d h / d t$ は定常状態 の勾配 $(\mathrm{mm} / \mathrm{hr}), h_{B}$ は低圧側容積決定の時の, 底部か ら B な゙の距離 $(\mathrm{mm}), h_{L}$ は底部からの水銀レベルの高 さ $(\mathrm{mm}), P_{1}$ は測定ガスの 圧力 $(\mathrm{mmHg}), P_{2}$ は透過 したガスによる低圧側の圧力 $(\mathrm{mmHg})$ で $\left(h_{L}-h\right), h$ は 測定開始前の水銀の高さ $(\mathrm{mm}), R$ 恰気体定数 $6.236 \times$ $10^{7} \mathrm{~mm}^{3} \cdot \mathrm{mmHg}^{\circ} \mathrm{K} \cdot \mathrm{mol}, V_{f}$ は Fig. 8-b で $B$ から $D$ ま での容積 $\left(\mathrm{mm}^{3}\right)$ である。この式は次の様に誘導される.

今 $\mathrm{n}$ モルの気体が低圧側に透過して来たとすると，

$$
n=\frac{P_{t} V_{t}}{R T} \text { したがって } n R T=P_{t} V_{t}
$$

$P_{t}, V_{t}$ は透過した気体の圧力拉よび体積を示す．低圧 側の容積が一定とみなせないということは $P_{t}, V_{t}$ も变 化することであり，次のように微分式で示めされる.

$$
R T d n=P_{t} d V+V_{t} d p
$$

$d V=-a d h, d p=-d h, P_{t}=\left(h_{L}-h\right), \quad V_{t}=\left[V_{f}+a\left(h_{B}-\right.\right.$ h)] であるから(19) 式より

$$
\begin{aligned}
& R T d n=-P_{t} a d h-V_{t} d h \\
& d n=\frac{-a\left(h_{L}-h\right) d h-\left[V_{f}+a\left(h_{B}-h\right)\right] d h}{R T}
\end{aligned}
$$



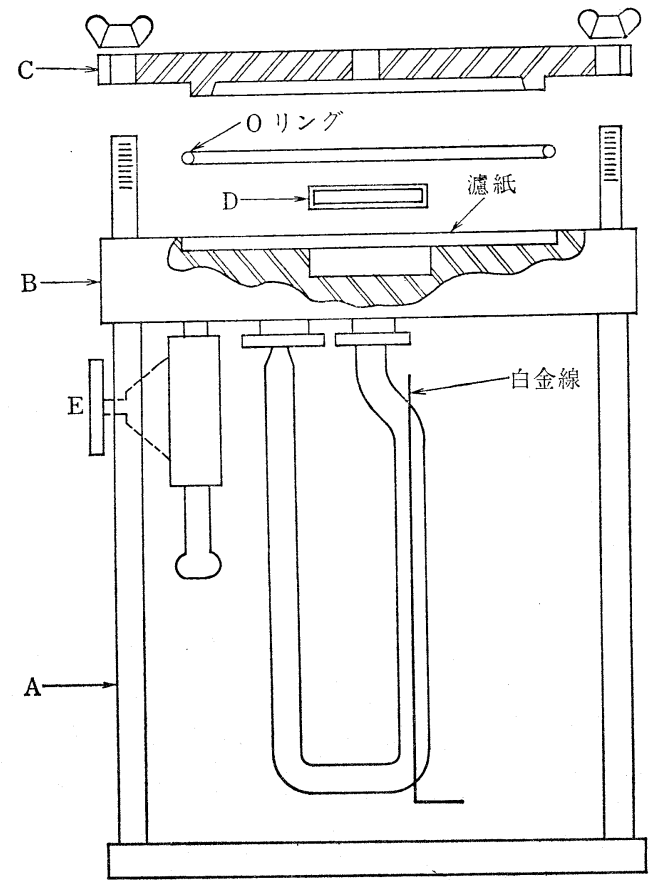

Fig. 8-a 低真空法に用いる気体透過セルマノメー タ (ASTM)

$\mathrm{A}$ : 架台, $\mathrm{B}$ : 下部プレート, C : 上部プレート, $\mathrm{D}:$ ア ダプター

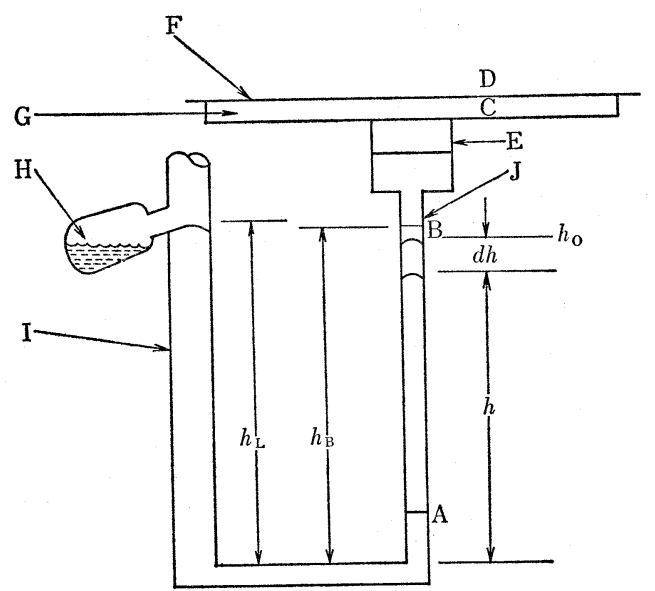

Fig. 8-b 透過セルマノメータ (ASTM) に打计る水銀柱の変化

$\mathrm{E}:$ ア ダプタースペース, $\mathrm{F}$ : 測定試料, $\mathrm{G}:$ 口 紙， $\mathrm{H}$ : 水銀だめ, I : 水銀だめ脚 $\mathrm{J}$ : 毛細管
したがって

$$
\begin{aligned}
& d n=\frac{d h\left[2 a h-a\left(h_{L}+h_{B}\right)-V_{f}\right]}{R T} \\
& \frac{d n}{d t}=\frac{d h}{d t}\left[\frac{2 a h-a\left(h_{L}+h_{B}\right)-V_{f}}{R T}\right]
\end{aligned}
$$

〔】内の值は一定の温度では透過セルによって定まる 值であり，セル定数 (cell constant) と呼ばれる. (22) 式は透過面積 $A \mathrm{~cm}^{2}$, 圧力差 $\left(P_{1}-P_{2}\right) \mathrm{mmHg}\left(P_{t}\right.$ と $P_{2}$ 注同じ), 1 時間あたり透過して来た気体のモル数 ( $d h / d t$ の単位に注意) であるとすると,

$$
R=\frac{d n}{d t} \times 22415 \times \frac{10000}{A} \times 24 \times \frac{760}{P_{1}-P_{2}}
$$

したがって，

$$
R=\frac{d h}{d t} \cdot \frac{4.09 \times 10^{12}}{\left(P_{1}-P_{2}\right) A}[\text { cell const }]
$$

\section{2 容積法}

この方法は気体透過度が比較的大きい測定試料あるい は高圧側の圧力が 100〜150 気圧といった高圧下での透 過の測定にも用いられている，容積法による透過ガスの 測定は低圧側の全圧が大気圧であり, 高圧側の圧力はこ れより高い圧力にして測定するため，透過してきた気体 により低圧側の体積が増加する速度から, 気体透過度, 気体透過係数を求める. Fig. 9 に測定装置の概略を, Fig. 10 に特に高圧にて測定する場合の透過セルの構造 を示す ${ }^{2)}$. 最近では海水の淡水化の研究に使用される逆 浸透測定装置の透過セルが普及しているから，これを応 用することも容易である．検出器としては低真空法の圧 力法によるマノメータのかわりに容積の増加を測定する 毛細管を用いる.

\section{[毛細管の較正]}

管の内径としては $0.25 ， 0.5 ， 1.0 \mathrm{~mm}$ が普通用いら れている.この内径の較正は重量を正確に測定した水銀 滴を入れ，読取り顕微鏡で毛細管中に占める水銀の距離 を正確に読む。この区間に括ける毛細管の平均の断面積 $a$ は $a=w / l d$ で求める. ここで $d$ は水銀の測定温度に 扣ける密度， $W$ は水銀の重量 $(\mathrm{g}), l$ は毛細管中の水銀 の距離 $(\mathrm{cm})$ である.

測定操作の手順

ASTM D 1434 V 法をもとに手順を以下に述べる.

1）圧力法と同様に測定試料を透過セルに装填する.

2）透過セルの高圧側，低圧側を測定ガスでフラッシ ニする. この操作のガスの流速は毎分 $100 \mathrm{cc}$ で 10 分間 流す.

3）液体を長い針の注射器を用いて，毛細管の上から 

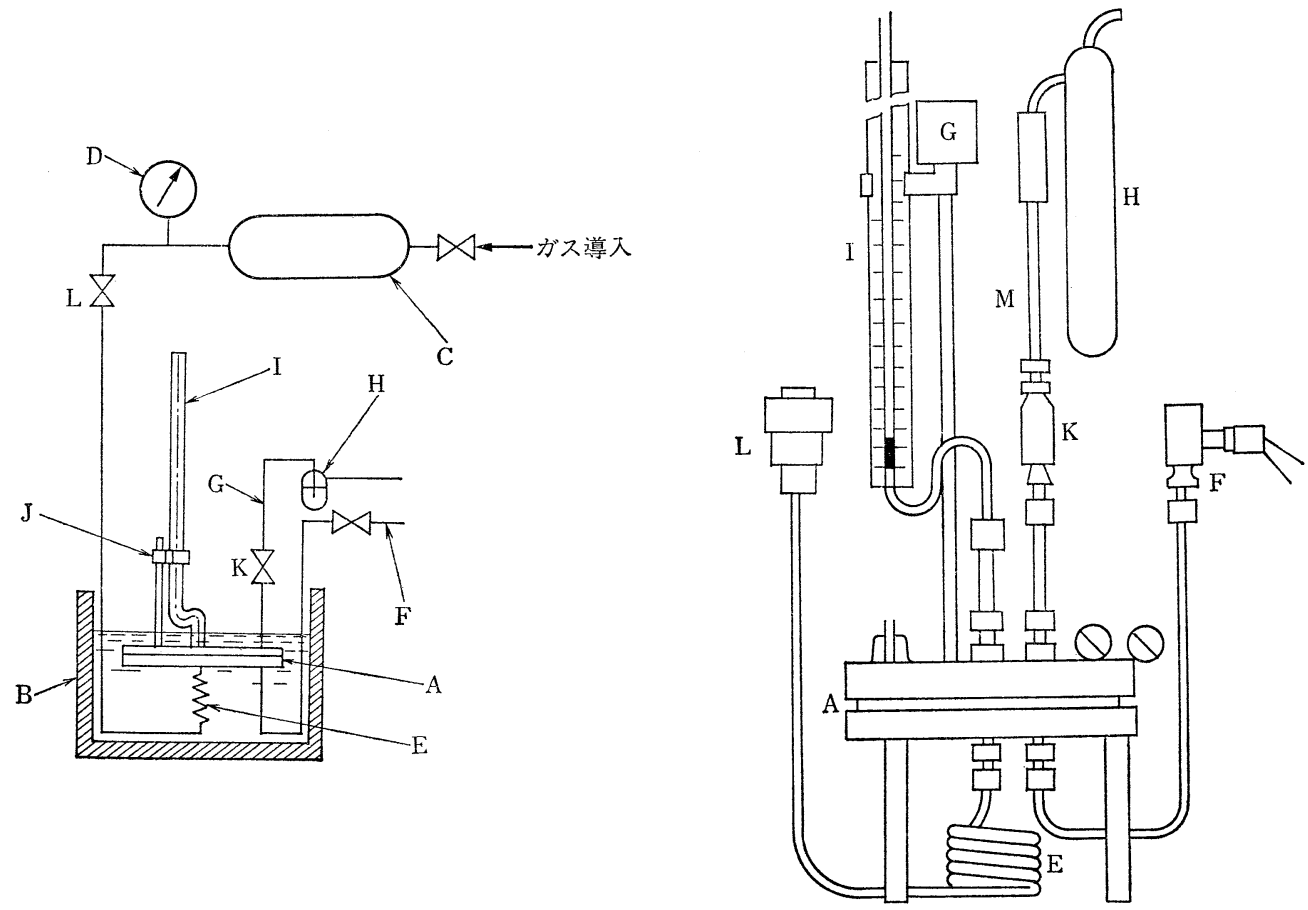

Fig. 9 容積法による気体透過測定装置 (ASTM D $1434 \mathrm{~V}$ 法)

$\mathrm{A}$ ：透過セル $\mathrm{B}$ ：恒温槽 $\mathrm{C}$ ：ガス供給タンク $\mathrm{D}$ ：圧力ゲージ $\mathrm{E}$ ：熱交換器 $\mathrm{F}:$ ベント・ラ イン $\mathrm{G}$ ：透過ガスベントライン $\mathrm{H}$ ：オイルトラップ I : ガラス毛細管 J : ガラス毛細管保持 具 $\mathrm{K}:$ バルブ $\mathrm{L}:$ コネクター $\mathrm{M}$ : バイブレーター

注意深く入れ， $2 \mathrm{~cm}$ の長さになるようにする。この液 体は 4-メチル-2-ペンタノンに適当な染料たと党ば Victoria Blue Base を混ぜたものである。この液体の蒸気 圧は $23^{\circ} \mathrm{C} て ゙ 7 \mathrm{mmHg}$ であり, やや粘稠であるため, 毛細管が細い場合は液体の移動は極めて遅いので平衡に 達するのに適当な時間が必要である.

4) 所定の圧力を高圧側に加え，ガスもれを調べる.

5）時間毎に毛細管の中の液体の上部のレベルの移動 量をカセトメータで読み透過曲線を作る。

\section{[計算式】}

$$
\begin{aligned}
R= & a \times \frac{B}{(273+t)} \times \frac{273}{76} \times \frac{10000}{A} \\
& \times \frac{76}{\Delta p} \times 24 \times \frac{d h}{d t}
\end{aligned}
$$

ここで, $a$ は毛細管の断面積 $\left(\mathrm{cm}^{2}\right), A$ は透過面積 $\left(\mathrm{cm}^{2}\right), B$ は測定中の大気圧 $(\mathrm{cmHg}), \Delta P$ 怡高圧側に 供給した気体の分圧差 $(\mathrm{cmHg}), t$ は測定中の室温 $\left({ }^{\circ} \mathrm{C}\right)$, $d h / d t$ は単位時間めたりの毛細管の液体の移動量 $(\mathrm{cm} / \mathrm{hr})$
である。

\section{3 圧力法による水蒸気共存下での気体透過測定 $\left.{ }^{3}\right)$}

水蒸気共存下の気体透過測定は後述する Modern Controls 社の Ox-Tran 100 による等圧法によって, 気体は酸素に限定されるが，一般に行われている。しか し, 水蒸気の存在によって著しく気体透過度が増大する ような測定試料の場合には “重祸わせ法”によって圧 力法により気体透過度を測定することができる。これは Fig. 11 に示す上うに测定試料と水蒸気透過度が小さく 気体透過度の大きい膜（たとえばポリエチレン膜）を重 初合わせ，測定試料を水蒸気供給側飞置き透過セルに装 填する.

この測定の原理は次のごとくである．まず水蒸気の透 過係数がかなり異なる膜を二枚重ねた系では水蒸気の濃 度分布は Fig. 11 で示される. 圧力法に拈いて, 水蒸 気を所定の圧力, 高圧側に導入し, 定常状態の透過が生 じているとすると，測定試料とポリエチレン膜の間の水 蒸気圧は次式で計算できる。単位面積, 単位時間あたり 


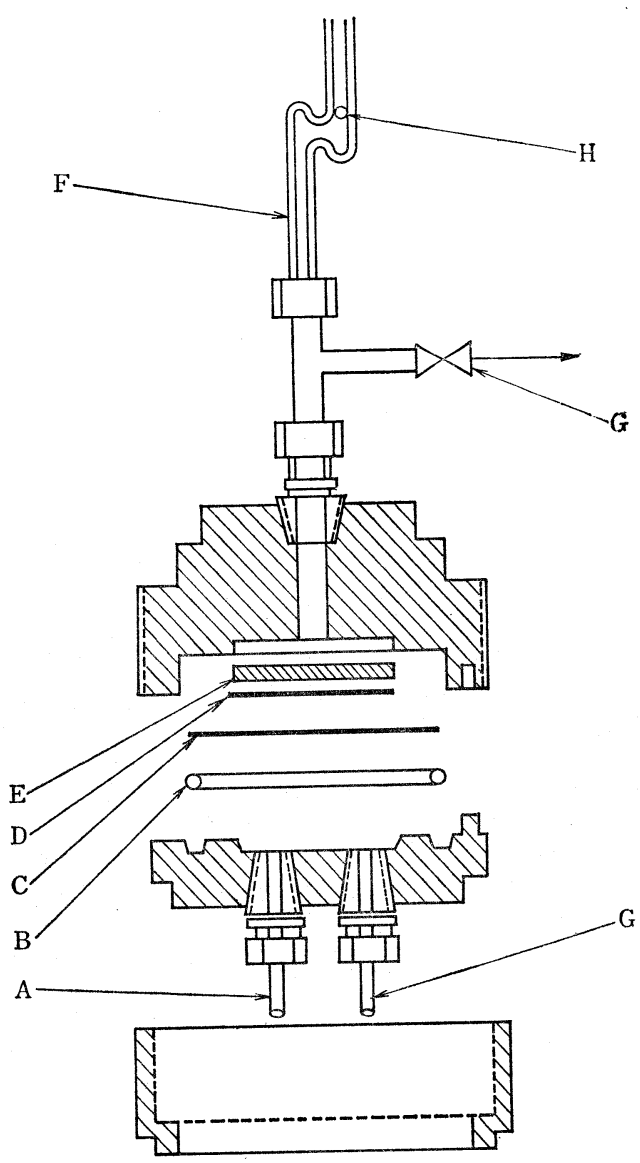

Fig. 10 容積法による超高圧用気体透過セル

$\mathrm{A}$ ：気体導入口， B ：ゴム O-リング， C : 測定試 料, D : 口紙, E : 多孔質ステンレス鋼, F：ガラ ス毛細管, $\mathrm{G}$ : 気体排出口, $\mathrm{H}$ : 液滴

の水蒸気の透過量 $q$ は,

$$
q=\frac{P_{W 1}\left(p_{1}-p_{2}\right)}{l_{1}}=\frac{P_{W 2}\left(p_{2}-p_{3}\right)}{l_{2}}
$$

ここで， $P_{W 1}, P_{W 2}$ はそれぞれ測定試料，ポリエチレン 膜の水蒸気の透過係数， $l_{1}, l_{2}$ はそれぞれの厚さである. $P_{3} \fallingdotseq 0$ であるから，(25）式より，

$$
p_{2}=\frac{P_{W 1} l_{2}}{P_{W 2} l_{1}+P_{W 1} l_{2}} \times p_{1}
$$

今簡単な系として，2種の膜厚が等しいとし， $P_{W 1}=100$, $P_{W 2}=1$, 水蒸気圧 $p_{1}, p_{2}$ のかわりに相対湿度を用い, 高圧側に飽和水蒸気圧を加えると，(26）式より

$$
p_{2}(\%)=\frac{100}{100+1} \times 100(\%)=99(\%)
$$

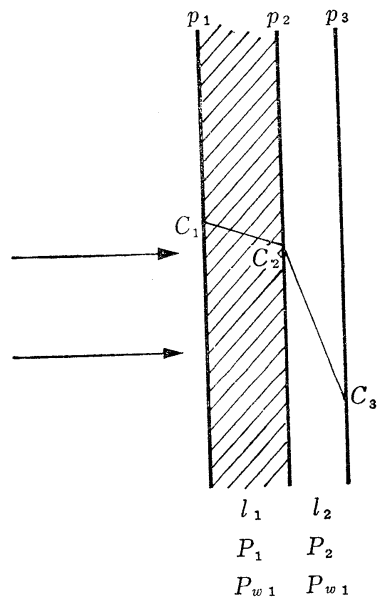

Fig. 11 重社合せ法による水蒸気共存下での 気体透過

測定試料とポリエチレンの界面は $99 \%$ の湿度となり，測 定試料はほぽ 100\%の相対湿度と平衡状態になっている。 この状態で, 測定しょうとする気体を導入し, 前述のご とく透過実験を行う．得られた二層全体の見か壮の透過 係数 $P$ と重㸚合わせ膜のそれぞれ透過係数 $p_{1}, p_{2}$ と 膜厚 $l_{1}, l_{2}$ の間には次の関係が容易に導かれる.

$$
\frac{L}{P}=\frac{l_{1}}{P_{1}}+\frac{l_{2}}{P_{2}}+\cdots \cdots
$$

ここで, $L$ は $l_{1}+l_{2}$ である.

$$
P_{1}=\frac{l_{1} p_{2} P}{L p_{2}+l_{2} P}
$$

水蒸気共存の気体透過係数を知ることができる.

\section{5. 等圧法による測定}

\section{1 熱電導度検出器を用いる方法}

高感度の熱電導度検出器の開発により, 透過ガスの検 出にこれを用いることができる. Fig. 12 に示すような 測定試料が保持されている透過セルの高圧側に測定ガス を流し，低圧側にキャリヤガスを流す．キャリヤガスは 測定ガスとの組合せでへリウムなどの各種の気体が用い られる．記録計に現われる時間対電圧の曲線は微分型の 透過曲線となる．この方法では各種の測定ガスに対して 検出感度を求めて打く必要がある.

透過度 $R$ は次式で計算される。

$$
\begin{array}{r}
R=a \cdot b \cdot c \cdot \frac{10000}{A} \times \frac{76}{p_{1}} \times 24 \times 60 \times 60 \\
{\left[\mathrm{~cm}^{3}(\mathrm{STP}) / \mathrm{m}^{2} \cdot 24 \mathrm{hr} \cdot \mathrm{atm}\right]}
\end{array}
$$

ここで $a$ は定常状態のシグナル $(\mathrm{mV}), b$ は低圧側の 
70 仲川：気体透過膜の性能評洒法

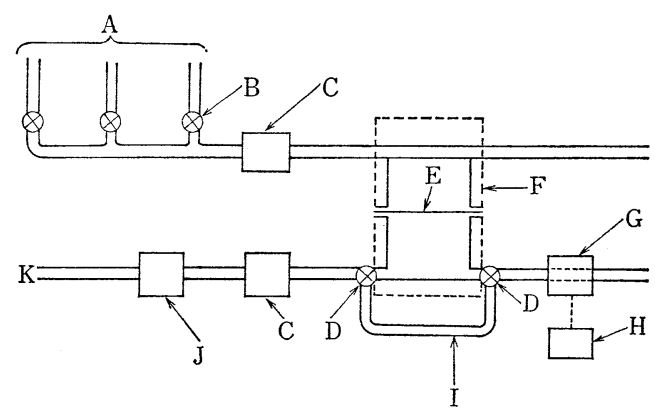

Fig. 12 熱伝導度検出器を用いた気体透過率 測定装置

$\mathrm{A}$ : 測定ガス, $\mathrm{B}$ : バルブ, $\mathrm{C}$ : 流量計, $\mathrm{D}$ : 三方 バルブ, $\mathrm{E}:$ 測定試料, $\mathrm{F}:$ 透過セル, $\mathrm{G}$ : 検出器, $\mathrm{H}$ : 記録計, $\mathrm{I}$ : バイパス, $\mathrm{J}$ : 流量調節器, $\mathrm{K}$ : キャリヤガス

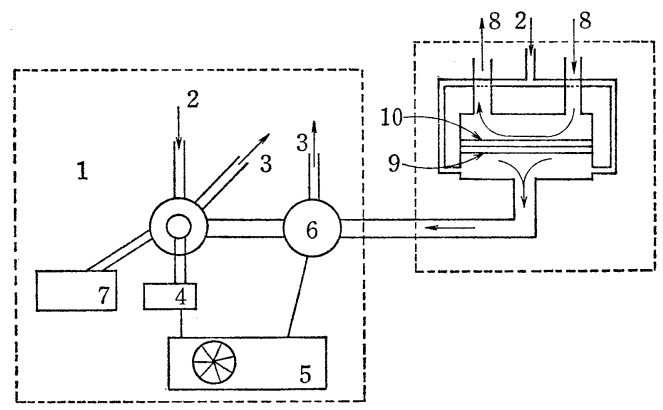

Fig. 13 等圧法による気体透過セル及び透過ガス をガスクロマトグラフに送る系統図

1: $5 \mathrm{~cm}^{3} \quad 2$ : 計量管キャリヤガス導入口 $3:$ ヘ ント 4: コック切換モーター 5: プログラマー 6: 電磁弁 7: ガスクロマトグラフ分析器 $8:$ 供給ガス出入口 9 : 多孔性ステンレス支持板 10 : 測定試料

キャリヤガスの流速 $\left(\mathrm{cm}^{3} / \mathrm{sec}\right) ， ＼mathrm{~ は 測 定 カ ゙ ス に 対 す る ~}$ 検出器の感度 $\left(\mathrm{cm}^{3}(\mathrm{STP}) / \mathrm{mV}\right), A$ は透過面積, $p_{1}$ は高 濃度側の測定ガズの圧力 $(\mathrm{cmHg})$ である.

\section{2 ガスクロマトグラフを用いる方法}

Fig. 13 に透過セル拉よびガスクロマトグラフに透過 しな気体をキャリヤガスと共に送り込む部分を示す。電 磁バルブ, コック切換モータ, プログラミングタイマー の連動で, 計量管のループに蓄えた後, ガスクロマトグ ラフに輸送する．注意すべき点は膜を透過した混合気体 を分析器へ送り込むときのキャリヤガスの流量の影響で める。すなわちキャリヤガスの流量が少ないと膜を透過 した成分がキャリヤガスによって完全に運ばれず結果的

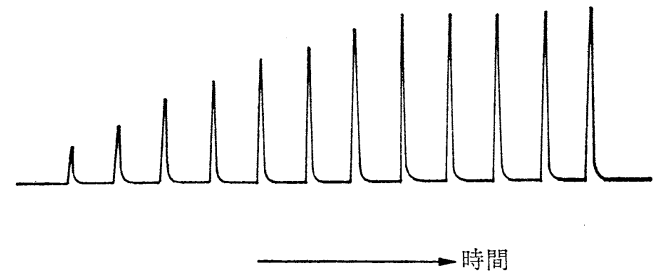

Fig. 14 透過ガス導入後ガスクロマトグラフに示 される吸収ピークの変化

に小さな透過度が求まることになる。一方キャリヤガス の流量が多すぎると系内が加圧状態となり，透過した気 体を含んだキャリヤガスでベントから逃げることになる。 この場合る小さな透過度が求まることになる，測定ガス を膜に供給すると同時にキャリヤガスを透過側に流すと Fig. 14 に示すようなピークの変化が見られる.このピ 一クの高さが一定となったときが定常状態である.

透過度 $R$ は次式に上り計算される.

$$
\begin{array}{r}
R=a \cdot b \cdot c \cdot V \times \frac{10000}{A} \times \frac{76}{p_{1}} \times 24 \times 60 \times 60 \\
{\left[\mathrm{~cm}^{3}(\mathrm{STP}) / \mathrm{m}^{2} \cdot 24 \mathrm{hr} \cdot \mathrm{atm}\right]}
\end{array}
$$

ここで $a$ は定常状態のピークの高さまたは面積（目盛 数), $b$ はキャリヤガスの流速 $\left(\mathrm{cm}^{3} / \mathrm{sec}\right), c$ は計量管 $\mathrm{V}$ $\mathrm{cm}^{3}$ あたり記録計の 1 目盛が示す測定気体の体積 $\left(\mathrm{cm}^{3}\right.$ $(\mathrm{STP}) /$ division $\left.\cdot \mathrm{cm}^{3}\right), V$ 以計量管の体積 $\left(\mathrm{cm}^{3}\right)$ である.

\section{3 酸素電極を用いる方法}

測定試料である膜を境界として，電極のある側に電解 液, 外側に酸素を含む水, あるいは直接酸素ガスを接触 させ，膜を透過して来た酸素を測定する方法として，つ ぎの電極反応に上る電流を測定する方法がある.

院極面での酸素の還元反応は

$$
\mathrm{O}_{2}+2 \mathrm{H}_{2} \mathrm{O}+4 \mathrm{e}^{-} \longrightarrow 4 \mathrm{OH}-
$$

陽極での反応は

$$
4 \mathrm{Ag}+4 \mathrm{Cl}-\longrightarrow 4 \mathrm{AgCl}+4 \mathrm{e}^{-}
$$

この反応で示されるように, 膜と陰極の密着が良好であ れば, 電解質中の酸素の拡散速度, 電極反応速度は, 膜 中の酸素の拡散速度に比べて極めて大きいために酸素の 膜中の移動が律速段階となる。この条件のもとで，膜に 対する酸素の透過係数が測定できる.

これを応用したものに酸素濃度計があり, 液中の酸素 濃度の測定にかなり以前から用いられていたが, 膜の性 能評価には測定試料の交換が容易なこと，水で膨潤した 機械的強度の弱い膜も測定できるような装置が新しく作 られ広く用いられている．Fig. 15 に測定装置の系統闵 を, Fig. 16 に電極の断面を示す。 


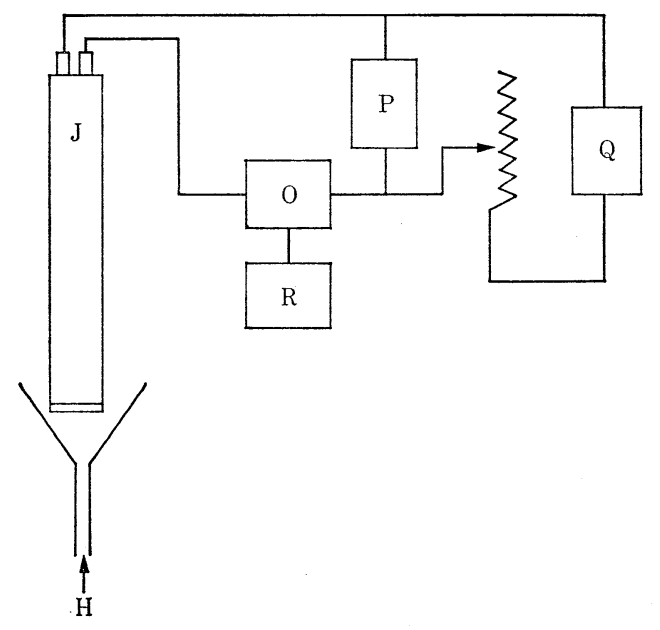

Fig. 15 酸素電極法の系統図
$\mathrm{J}:$ 電極棒
$\mathrm{H}$ ：室素または酸素導入口
$\mathrm{O}$ : 微少電流計
$\mathrm{P}$ : 電圧計 $\mathrm{Q}$ ：バッテリ
$\mathrm{R}$ ：記録計

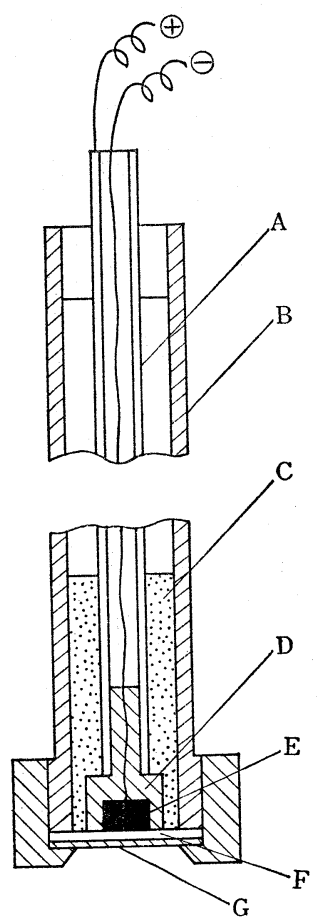

Fig. 16 酸素電極の断面図

$\mathrm{A}$ : 陽極, B : 外管, C : $0.5 \mathrm{NKCl}, \mathrm{D}$ : 絶縁材 料, $\mathrm{E}$ : 白金陰極, $\mathrm{F}$ : 測定試料, $\mathrm{G}$ ：支持板

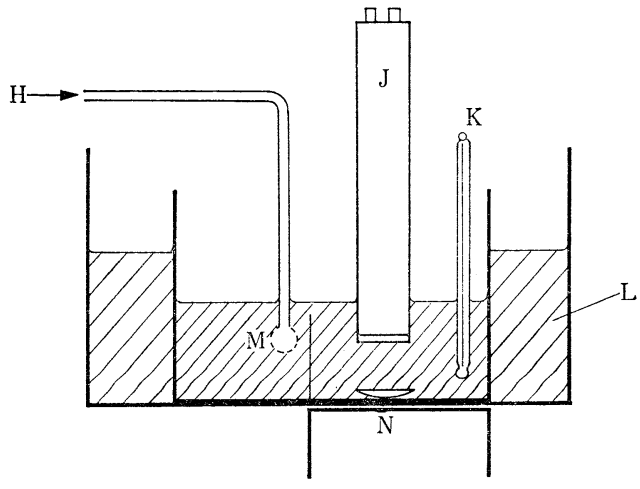

Fig. 17 水共存下での酸素電極の用い方 $\mathrm{J}$ : 電極棒 $\mathrm{K}$ : 温度計 $\mathrm{L}$ 恒温水槽 $\mathrm{M}$ ：ガスバブルロ $\mathrm{H}$ : 窒素及び酸素導入口

\section{〔測定操作の手順】}

1）保護管に測定試料を装填し， 0.5 規定の塩化力リ ウムの溶液を入れる。

2）電極棒を保護管に插入し，電流が測定できるよう 配線し, 分解電圧として $-0.7 \mathrm{~V}$ を陰極に印加する.

3）窒素ガスを満たした容器中に電極を置くか, める いは測定試料面に窒素ガスを流し, 電流計を安定させ, 記録計を調整する。

4) 酸素分纴の既知の容器中に電極を移し, 女るいは 酸素ガスを測定試料面に接触させる.

また水共存下で酸素透過度を測定するには, 電極棒を Fig. 17 に示すごとくに固定し，まず水に窒素ガスを注 いで電流值が事実上 0 を示すようにし，ついで窒素ガス のかわりに酸素ガスを導入する．また拡散係数を求める 場合は，あらかじめ酸素ガスで飽和した水を一気に注ぎ， 直らに酸素ガスをバブルする.

5）平衡電流を微少電流計で読取るか，記録計に電流 を記録させ，透過の微分曲線を得る。

装置は市販されているが試作する場合は, 長さ約 15 $\mathrm{cm}$ の銀製パイプの一端に絶縁材を介して直径 $5 \mathrm{~mm}$, 高さ $5 \mathrm{~mm}$ 程度の円柱状の白金を固定し，これをステ ンレススチール製の外管に插入する，測定試料の着脱の 容易さと, 電解液のもれを防ぐシールに, 真空技術で用 いられているコンプレッションシールを利用する。電流 計には $10^{-6} \sim 1$ アンペアの電流が測定できる無抵抗電 流計を用いる。

[計算式]

1) 定常電流より透過係数の計算式 


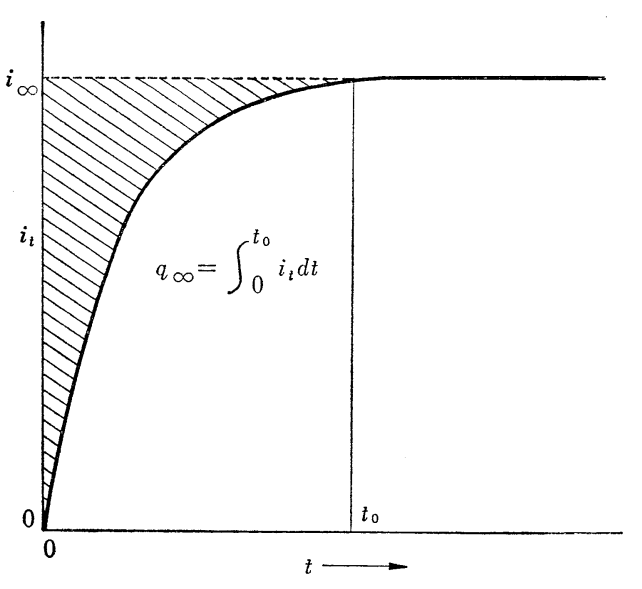

Fig. 18 酸素電極を用いたときの透過曲線

酸素分圧の段階的な変化に対して酸素電極が示す非定 常電流 $i_{t}$ は次式で示される。

$$
i_{t}=N \cdot F \cdot A \cdot D\left(\frac{\partial^{2} c}{\partial x^{2}}\right)
$$

ここで， $N$ は反応に関与する電子数で酸素の場合 $4, F$ はファラディ定数 (96500クーロン/22400), $A$ は陰極面 積 $\left(\mathrm{cm}^{2}\right), i_{t}$ は非定常電流 $(\mu \mathrm{A}), C$ は膜中の酸素濃度 $\left(\mathrm{g} / \mathrm{cm}^{3}\right)$ である.（31）式の $D\left(\frac{\partial^{2} C}{\partial x^{2}}\right)$ は式 (12) を解い たと同じ条件で解くことができ，全く同様の経過で，t $=\infty$ の電流を $i_{\infty}$ (定常電流) とすると,

$$
\begin{aligned}
i_{\infty} & =N \cdot F \cdot A \cdot D \frac{C_{1}}{l} \\
& =N \cdot F \cdot A \cdot P \frac{P_{1}}{l}
\end{aligned}
$$

したがって，透過係数 $P$ は

$$
P=\frac{i_{\infty} \cdot l}{N \cdot F \cdot A \cdot P_{1}}
$$

測定例として, 厚さ $4.2 \times 10^{-3} \mathrm{~cm}$, のポリプロピレ ン膜の酸素透過実験で, 酸素圧 $76.0 \mathrm{cmHg}$, 面積 0.196 $\mathrm{cm}^{2}$ 陰極を用いた時平衡電流 $8.6 \mu \mathrm{A}$ が得られとすると,

$$
\begin{gathered}
P=\frac{\left(8.6 \times 10^{-6}\right)\left(4.2 \times 10^{-3}\right)}{4 \times \frac{96500}{22400} \times 0.196 \times 76.0}=1.4 \times 10^{-10} \\
\mathrm{~cm}^{3}(\mathrm{STP}) \cdot \mathrm{cm} / \mathrm{cm}^{2} \cdot \mathrm{sec} \cdot \mathrm{cmHg}
\end{gathered}
$$

2) 非定常電流より拡散係数の計算

(31) 式の二次微分の部分を（12）式を解いたと同様に 解き, $i_{t} を t=0$ より定常電流が得られる時間 $t_{0}$ まで 積分与ると,

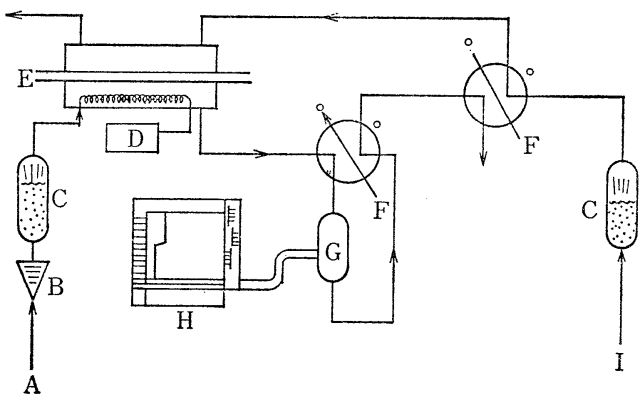

Fig. 19 酸素電極を応用した酸素透過度測定装置 Ox-Tran 100 の系統図
$A$ ：窒素導入口
$\mathrm{B}$ : 流量計
$\mathrm{C}$ ：調湿部
$\mathrm{D}$ : 温度調節器
$\mathrm{E} ：$ 測定試料 $\mathrm{F} ：$ 切換コック
$\mathrm{G}:$ 酸素電極
$\mathrm{H}$ ：記録訪
I ：酸素奨入口

$$
\int_{0}^{t_{0}} i_{t} d t=q_{\infty}=N \cdot F \cdot A \cdot D \frac{C_{1}}{l}\left(t_{0}-\frac{l^{2}}{6 D}\right)
$$

（35）式に（32）式を代入すると

$$
q_{\infty}=i_{\infty}\left(t_{0}-\frac{i^{2}}{6 D}\right)
$$

したがって

$$
D=\frac{l^{2} \cdot t_{\infty}}{6\left(i_{\infty} t_{0}-q_{\infty}\right)}
$$

$\left(i_{\infty} \bullet t_{0}-q_{\infty}\right)$ は Fig. 18 に示した微分曲線の斜線を引い た箅所の面積に等しく, グラフ的にはこの值を求めて $D$ を計算する。

水共存下での酸素透過で注意すべき点は透過係数が $10^{-9}$ あるいは $10^{-8}\left[\mathrm{~cm}^{3}(\mathrm{STP}) \cdot \mathrm{cm} / \mathrm{cm}^{2} \cdot \mathrm{sec} \cdot \mathrm{cmHg}\right] の$ オーダにある測定試料の場合, 膜の界面に存在する “動 かない水の層”が酸素透過に対し影響を及傿すことであ る. 材料自身の值を求めるにはこの水の層の影響を除か なければならない，奏験的には厚さを異にする測定試料 について見かけ上の $P$ を測定し, 厚さの逆数に対し $P$ の逆数をプロットし, 原点に外插して $P$ 学求めれば良 い.

Modern Contrals 社から市販されている Ox-Tran 100 も検出器は酸素電極の一種である。この装置の系統図を Fig. 19 に示す． E は測定試料の膜で I は酸素ガスの導 入口であり，Cで調湿されて膜上を流れる，Aは壹素が スの導入口で， B は流量計，Cで調湿され，透過した酸 素ガスを運び，酸素電極 $\mathrm{G} て ゙$ 検出され，Hに記録される. 検量線をあらかじめ求めて打きこれと対比して透過度を 求める。 


$$
\text { 文献 }
$$

1) H. A. Daynes: Proc. Roy. Soc. (London) A97, 286 (1920); R. M. Barrer: Trans. Faraday Soc., 35, 628 (1937)

1) S. A. Stern, P. J. Gareis, T. F. Sinclair, P. H. Mohr: J. Appl. Polymer Sci., 7, 2035 (1963)

3) J. V. Schmitz: "Testing of Polymers,"' vol. 1, John Wiley \& Sons, Inc., (1965), p.410
4) R. A. Pasternak, J. F. Schimscheimer, J. H. Heller: J. Polymer Sci., A-2, 8, 467 (1970)

5) 箕浦憲彦, 浜谷健生, 上恒善彦, 仲川 勤：製品科 学研究所報告, 87, 47 (1979)

6) 箕浦憲彦, 仲川 勤：日本化学会誌, 1976, 1271

7) S. Aiba, M. Ohashi, S. Y. Huang: Ind. Eng. Chem. (Found) 7, 497 (1968) 